\title{
Bacteriospermia and Its Impact on Basic Semen Parameters among Infertile Men
}

\author{
Sangeetha Vilvanathan, ${ }^{1}$ Balan Kandasamy, ${ }^{1}$ Abiramy Lakshmy Jayachandran, ${ }^{1}$ \\ Sarasa Sathiyanarayanan, ${ }^{1}$ Vijayalakshmi Tanjore Singaravelu, ${ }^{1}$ \\ Veeraraghavan Krishnamurthy, ${ }^{2}$ and Vanithadevi Elangovan ${ }^{1}$ \\ ${ }^{1}$ Department of Microbiology, Karpaga Vinayaga Institute of Medical Sciences and Research Centre, \\ Chinna Kolambakkam Post, Madurantakam Taluk, Kanchipuram, Tamil Nadu 603 308, India \\ ${ }^{2}$ Department of Medical Gastroenterology, Rajiv Gandhi Government General Hospital, Chennai, Tamil Nadu 600003 , India
}

Correspondence should be addressed to Sangeetha Vilvanathan; sangeetha_v100@yahoo.com

Received 22 October 2015; Revised 15 December 2015; Accepted 20 December 2015

Academic Editor: Subhada Prasad Pani

Copyright (C) 2016 Sangeetha Vilvanathan et al. This is an open access article distributed under the Creative Commons Attribution License, which permits unrestricted use, distribution, and reproduction in any medium, provided the original work is properly cited.

\begin{abstract}
Introduction. Semen analysis is considered as the surrogate marker for male fecundity while assessing infertile men. There are several reasons for altered semen quality and bacteriospermia could be one among them. Thereby the aim of our work is to study the semen culture and its impact on semen parameters among infertile men. Materials and Methods. Semen samples were collected from men attending infertility clinic. Semen parameters were analysed based on WHO guidelines. Also, samples were subjected to culture using standard bacteriological techniques. Results. A total of 85 samples were collected. A number of 47 (55.30\%) had normal sperm count, 37 (43.50\%) had oligozoospermia, and one (1.17\%) had azoospermia. Teratozoospermia was the most common abnormality observed ( $81.17 \%)$ followed by asthenozoospermia $(28.23 \%)$. The prevalence of bacteriospermia was $35.3 \%$. Enterococcus faecalis (30\%) was the most common organism isolated followed by Coagulase negative Staphylococcus (23.33\%), Staphylococcus aureus (20\%), and E. coli (10\%). Other less frequently isolated organisms were Klebsiella pneumoniae (6.66\%), Proteus sp. (6.66\%), and Citrobacter sp. (3.33\%). Conclusion. The presence of asymptomatic bacteriospermia did not correlate with abnormal semen parameters.
\end{abstract}

\section{Introduction}

Infertility, a condition being different from various existing health related issues, in involving psychological and social aspects, affects $10-15 \%$ of couples in the reproductive age group [1]. Both sexes are more or less equally involved. Men, either alone or along with their female partners, contribute to $40-45 \%$ cases of infertility [2]. Furthermore, infectious etiologies involving bacteria, virus, fungi, and protozoa contribute to $15 \%$ of male factor infertility [3-5].

Bacteriospermia affects the normal fertility process by any of these following mechanisms: deterioration of spermatogenesis, decreased sperm motility, altered acrosome reaction, altered morphology, formation of reactive oxygen species leading to increased DNA fragmentation index, formation of antisperm antibodies due to breach in the blood-testes barrier, and genital tract obstruction due to inflammation and fibrosis [5-8].

Majority of these genitourinary tract infections remain asymptomatic, thereby leading to a dilemma whether to treat these patients or not. Evidences are being accumulating on the association of asymptomatic bacteriospermia and altered semen quality. Therefore, in this study, we have planned to determine the seminal patterns and prevalence of bacteriospermia and their impact on semen quality among infertile men.

\section{Materials and Methods}

Semen samples from 85 male partners of infertile couple attending infertility clinic in a tertiary care hospital were collected during the study period of June 2014 to June 2015. 


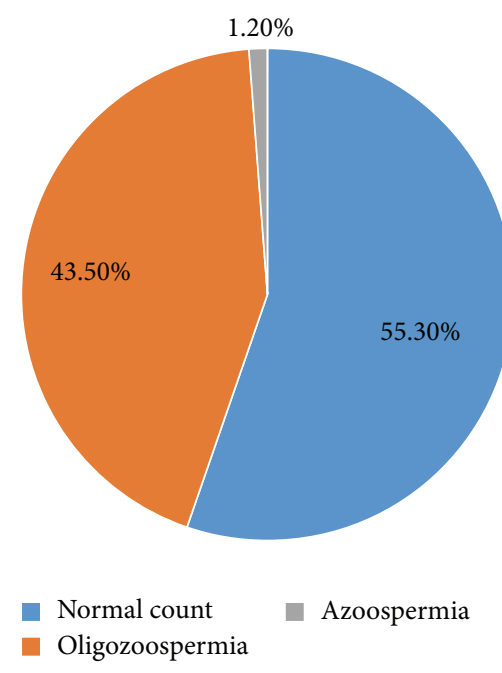

FIGURE 1: Semen density pattern of the study population.

Samples were collected in sterile containers by masturbation after a minimum abstinence period of 3 days. None of the patients had taken prior antibiotics.

Semen parameters such as appearance, volume, $\mathrm{pH}$, viscosity, liquefaction, count, motility, morphology, presence of other cells like epithelial cell or round cell, and sperm agglutination were recorded according to the WHO guidelines [9]. Gram stain and culture of the samples in blood agar and MacConkey agar were done in microbiology laboratory within 3 hours of specimen collection as per WHO guidelines [10]. Cultures were incubated at $37^{\circ} \mathrm{C}$. Those organisms which were isolated in a concentration of $>10^{3} \mathrm{cfu} / \mathrm{mL}$ were considered as significant [11]. Antimicrobial sensitivity testing by Kirby-Bauer disc diffusion method was done to the isolated organisms as per standard guidelines [12].

\section{Statistical Analysis}

The prevalence of bacteriospermia was calculated from the proportion of positive cases to the total number of study populations and expressed as percentages. The relationship between bacteriospermia and other semen parameters was analysed using Chi-square test.

\section{Results}

During the study period, 85 semen samples were received in the infertility clinic from male partners of infertile couples. The mean age group of the study population was 33.09. A number of $18(21.17 \%)$ men were in the age group of $<30$ years and $67(78.82 \%)$ men were belonging to the age group of $>30$ years.

Among the 85 specimens examined based on WHO guidelines [9], 47 (55.30\%) had normal sperm count, 37 (43.50\%) had oligozoospermia (spermatozoa concentration less than 15 million per milliliter), and 1 (1.17\%) had azoospermia (absence of spermatozoa in the ejaculate) (Figure 1).
TABLE 1: Comparison of abnormal semen parameters between individuals with normal sperm count and oligozoospermia.

\begin{tabular}{lccc}
\hline Parameter & Oligozoospermia & $\begin{array}{c}\text { Normal sperm } \\
\text { count }\end{array}$ & $P$ value \\
\hline Motility $(<32 \%)$ & 16 & 8 & 0.0208 \\
Morphology $(<4 \%)$ & 38 & 31 & 0.0002 \\
\hline
\end{tabular}

TABLE 2: Various organisms isolated and their frequency.

\begin{tabular}{lcc}
\hline Organism & Number & Percentage \\
\hline Enterococcus faecalis & 9 & 30 \\
Coagulase negative Staphylococcus & 7 & 23.33 \\
Staphylococcus aureus & 6 & 20 \\
Escherichia coli & 3 & 10 \\
Klebsiella pneumoniae & 2 & 6.66 \\
Proteus sp. & 2 & 6.66 \\
Citrobacter sp. & 1 & 3.33 \\
\hline
\end{tabular}

Morphological abnormality (teratozoospermia) was the most common abnormality observed in $69(81.17 \%)$ subjects followed by abnormalities in the motility (asthenozoospermia) in $24(28.23 \%)$ subjects.

Multiple abnormalities such as oligoasthenoteratozoospermia, oligoteratozoospermia, and asthenoteratozoospermia were detected in 19 (22.35\%), 28 (32.94\%), 4 (4.71\%), and $1(1.17 \%)$ specimens, respectively (Figure 2$)$. All the other parameters such as $\mathrm{pH}$, viscosity, volume, liquefaction, and antisperm antibodies were found to be normal.

Asthenozoospermia and teratozoospermia were more common among oligospermic individuals than the individuals with normal sperm count and the association was found to be statistically significant (Table 1).

Bacteriospermia was seen in 30 (35.29\%) samples. Enterococcus faecalis $(30 \%)$ was the most common organism isolated followed by Coagulase negative Staphylococcus (23.33\%), Staphylococcus aureus (20\%), and E. coli (10\%). Other less frequently isolated organisms were Klebsiella pneumoniae (6.66\%), Proteus sp. (6.66\%), and Citrobacter sp. (3.33\%) (Table 2). One of the K. pneumoniae was isolated from a case where necrozoospermia was demonstrated. Also noted were leukospermia, altered color, and odor of the semen in this patient.

No definite relationship was established between semen parameters and bacteriospermia (Table 3 ).

The altered semen quality among different bacterial species also lacks significant association (Table 4).

Antibiotic susceptibility testing using Kirby-Bauer disc method showed one vancomycin resistant $E$. faecalis and three carbapenem resistant Gram-negative isolates (Table 5).

\section{Discussion}

The incidence of infertility increases as the age of both partners increases [13]. Due to varied reasons, marriages and subsequently the age of first child birth are getting delayed, 


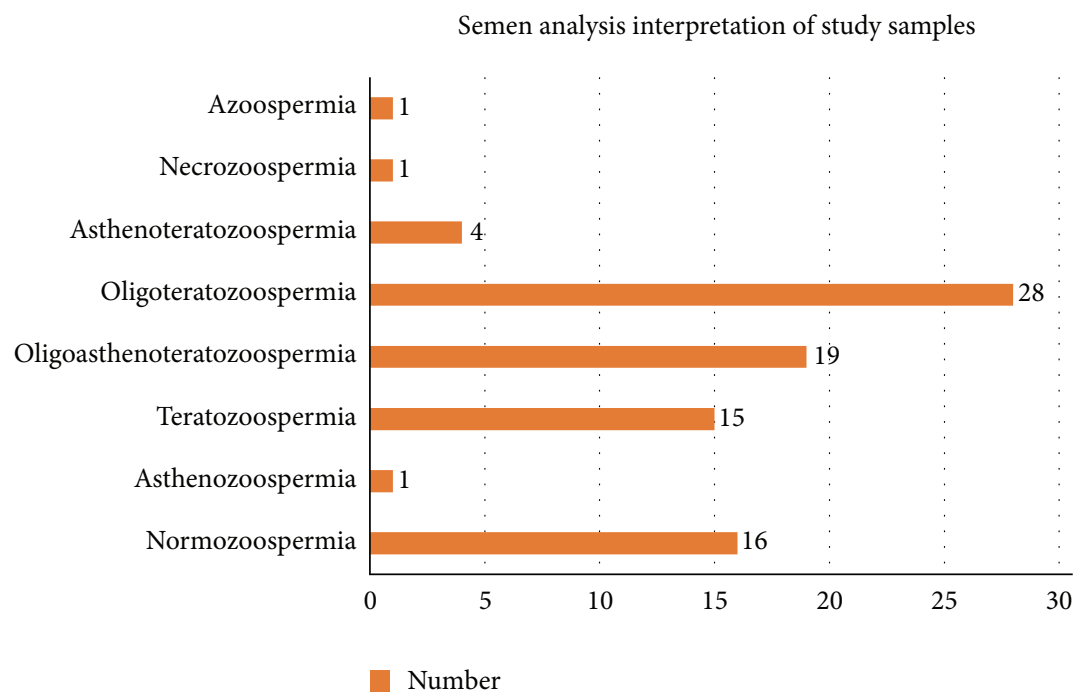

FIGURE 2: Interpretation of seminal parameters among study population.

TABLE 3: Comparison of semen parameters among bacteriospermic and nonbacteriospermic samples.

\begin{tabular}{|c|c|c|c|}
\hline Parameter & Bacteriospermia & Nonbacteriospermia & $P$ value \\
\hline Sperm concentration & & & 0.1838 \\
\hline$<15$ million $/ \mathrm{mL}$ & 10 & 28 & \\
\hline$\geq 15$ million $/ \mathrm{mL}$ & 20 & 27 & \\
\hline Motility & & & 0.8124 \\
\hline$<32 \%$ & 8 & 16 & \\
\hline$\geq 32 \%$ & 22 & 39 & \\
\hline Morphology & & & 0.2820 \\
\hline$<4 \%$ & 22 & 47 & \\
\hline$\geq 4 \%$ & 8 & 8 & \\
\hline
\end{tabular}

TABLE 4: Semen parameters among various bacterial species.

\begin{tabular}{|c|c|c|c|c|c|c|}
\hline \multirow{2}{*}{ Bacteria } & \multicolumn{2}{|c|}{ Count } & \multicolumn{2}{|c|}{ Motility } & \multicolumn{2}{|c|}{ Morphology } \\
\hline & $\geq 15$ million $/ \mathrm{mL}$ & $<15$ million $/ \mathrm{mL}$ & $\geq 32 \%$ & $<32 \%$ & $\geq 4 \%$ & $<4 \%$ \\
\hline E. faecalis & 5 & 4 & 6 & 3 & 2 & 7 \\
\hline CoNS & 4 & 3 & 6 & 1 & 1 & 6 \\
\hline S. aureus & 4 & 2 & 4 & 2 & 1 & 5 \\
\hline E. coli & 3 & 0 & 3 & 0 & 1 & 2 \\
\hline K. pneumoniae & 1 & 1 & 1 & 1 & 1 & 1 \\
\hline Proteus sp. & 2 & 0 & 1 & 1 & 2 & 0 \\
\hline Citrobacter & 1 & 0 & 1 & 0 & 0 & 1 \\
\hline
\end{tabular}

$P$ values were $>0.05$.

TABLE 5: Antibiotic susceptibility profile of bacterial isolates.

\begin{tabular}{|c|c|c|c|c|c|c|c|c|}
\hline Organism & $\mathrm{Cx}$ & $\mathrm{Va}$ & $\mathrm{A}$ & $\mathrm{G}$ & $\mathrm{Ak}$ & Cf & $\mathrm{Caz}$ & $\operatorname{Imp}$ \\
\hline E. faecalis & & $8(89)$ & $6(67)$ & $6(67)$ & & $8(89)$ & & \\
\hline S. aureus & $6(100)$ & $6(100)$ & $0(0)$ & $3(50)$ & & $4(67)$ & & \\
\hline Staphylococcus sp. & $5(71.4)$ & $7(100)$ & $2(28.6)$ & $7(100)$ & & $7(100)$ & & \\
\hline E. coli & - & - & $2(66.7)$ & $2(66.7)$ & $3(100)$ & $2(66.7)$ & $2(66.7)$ & $3(100)$ \\
\hline K. pneumoniae & - & - & $0(0)$ & $2(100)$ & $2(100)$ & $2(100)$ & $1(50)$ & $1(50)$ \\
\hline Proteus sp. & & & $1(50)$ & $2(100)$ & $2(100)$ & $2(100)$ & $1(50)$ & $2(100)$ \\
\hline Citrobacter sp. & & & $1(100)$ & $0(0)$ & $1(100)$ & $0(0)$ & $1(100)$ & $1(100)$ \\
\hline
\end{tabular}

Cx, cefoxitin; Va, vancomycin; A, ampicillin; G, gentamycin; Ak, amikacin; Cf, ciprofloxacin; Caz, ceftazidime; Imp, imipenem. 
thereby subsequently increasing the infertility rates. Our study also depicts the same with majority of men $(78.82 \%)$ aged above 30 years undergoing infertility evaluation. Based on the sperm count, nearly half of the study population was found to be oligospermic, as normal sperm count was observed only in $55.3 \%$ of study population.

When analysing each semen parameter individually, teratozoospermia (81.17\%) was the most common abnormality observed in this study. Our findings go hand in hand with those of Jajoo and Kalyani [14] and Owolabi et al. [15] stating teratozoospermia as the most common abnormality in infertile men.

Combining all parameters, abnormal semen quality was observed in $81.17 \%$ of samples and oligoteratozoospermia was the most common form of seminal presentation in this study while oligozoospermia was the commonest form of seminal male infertility in a study by Alekwe et al. [16].

Abnormalities in motility and morphology were more commonly observed among oligospermic individuals than normospermic and this was statistically significant. Owolabi et al. also reported the same [15].

The prevalence of bacteriospermia in this study was $35.3 \%$. Similar prevalence rate $(35.22 \%)$ was observed in a study by Golshani et al. [17]. Higher prevalence rates of $42.9 \%$, $51.7 \%, 52.5 \%, 65.7 \%, 66 \%$, and 79\% were shown by Mogra et al. [18], Cotell et al. [19], Alekwe et al. [16], Isaiah et al. [20], Merino et al. [21], and Damirayakhian et al. [22], while Domes et al. have demonstrated lesser $(15 \%)$ prevalence rate of bacteriospermia [11].

Among the various bacteria isolated, E. faecalis (30\%) predominated in this study which is in comparison with other studies by Domes et al. [11], Balmelli et al. [23], Ostwal [24], and Moretti et al. [25]. However, in few studies, Staphylococcus aureus and S. epidermidis were found to be more commonly isolated $[15,16,20,26-28]$.

None of the semen parameters were significantly affected in this study's bacteriospermic samples, which have been reported in many other studies investigating bacteriospermia in infertile men $[11,19,29,30]$. Though we come across a good number of works on asymptomatic bacteriospermia, query on its impact on infertility still exists. Cotell et al. and few others have shown the presence of bacteria in semen as just contaminants [19]. Ombelet et al. described that the presence of bacteria in seminal fluid in infertile men could be similar to fertile, with its clinical significance being still a matter of debate [31]. However, bacteriospermia was significantly associated with semen quality in studies by Isaiah et al. [20] (with sperm count) and Golshani et al. (with motility and morphology) [17].

Concerning E. faecalis, Staphylococcus aureus, and Coagulase negative Staphylococci, despite being more frequently isolated from teratozoospermic men, the finding was not supported by statistical significance in our work. This might be due to the lesser number of isolates observed in this study. A work done by Alekwe et al. projected that Enterococcus faecalis were commonly isolated from teratozoospermic infertile males with a statistically significant association $(P<0.001)$ [16]. Also, Moretti et al. studying the ultrastructural effect of E. faecalis on spermatozoa concluded that it compromises as the sperm concentration and morphology but not sperm motility [25].

We had an isolate of Klebsiella in a case where semen parameters were negatively influenced by this bacterium. Though we lack statistical significance, we can probably say that Klebsiella could be the cause of necrozoospermia in this individual as the semen had plenty of pus cells and yellowish colour with offensive odor. No definite relation was obtained between the type of bacteria and semen parameters in this study which is also shown by Mogra et al. [18]. However, association of $E$. coli with reduced semen density and motility has been observed in few studies [32-35]. Similarly negative impact of E. faecalis, E. coli, U. urealyticum, and M. morganii on sperm concentration and morphology was shown by Moretti et al. [25]. Rodin et al. demonstrated that samples with Streptococcus viridans and E. faecalis negatively affected semen quality [26]. Oyeyipo et al. observed that S. aureus, E. coli, and $S$. saprophyticus caused the most negative effect on sperm morphology and motility [36].

Merino et al. [21] and Ekhaise and Richard [27] showed that motile spermatozoa and viability were lower when the microorganisms were present in the semen. Huwe et al. also observed the same finding in Candida albicans along with the other bacteria [37]. Bornman established that the morphological abnormalities of spermatozoa were seen in samples where Mycoplasma and Ureaplasma had grown [38]. Eggert-Kruse et al. [39] and Kiessling et al. [40] have demonstrated that anaerobes do grow in semen in significant proportion; however, their role in infertility yet remains to be studied.

Despite works being done using a standard definition for bacteriospermia, it is still a dilemma to call it mere contaminants or asymptomatic infection. Such an inability to have a clear cut differentiation may account for not demonstrating any deterioration in the semen parameters in bacteriospermic samples in this study. Added to this could be the absence of methods employed to detect other bacteria like Chlamydia, Mycoplasma, Ureaplasma, and anaerobes in this study due to technical difficulties. All the above findings question the routine treatment of asymptomatic bacteriospermic men with antibiotics. In this study, we had one vancomycin resistant Enterococcus faecalis and three carbapenem resistant Gram-negative bacilli.

To conclude, we had not obtained any positive association of asymptomatic bacteriospermia and infertility in this study. However, as the semen analysis is quite different from other investigations in being having the potential to determine the future generation, further precise studies should be planned to highlight the role of asymptomatic bacteriospermia in infertility by conducting randomized control trials and evaluating the treatment outcomes of asymptomatic bacteriospermia.

\section{Conflict of Interests}

The authors declare that there is no conflict of interests regarding the publication of this paper. 


\section{References}

[1] P. K. Deka and S. Sarma, "Psychological aspects of infertility," British Journal of Medical Practitioners, vol. 3, no. 3, article a336, 2010.

[2] S.-L. Weng, C.-M. Chiu, F.-M. Lin et al., "Bacterial communities in semen from men of infertile couples: metagenomic sequencing reveals relationships of seminal microbiota to semen quality," PLoS ONE, vol. 9, no. 10, Article ID el10152, 2014.

[3] T. Diemer, P. Huwe, M. Ludwig, E. W. Hauck, and W. Weidner, "Urogenital infection and sperm motility," Andrologia, vol. 35, no. 5, pp. 283-287, 2003.

[4] F. R. Ochsendorf, "Sexually transmitted infections: impact on male fertility," Andrologia, vol. 40, no. 2, pp. 72-75, 2008.

[5] C. Keck, C. Gerber-Schäfer, A. Clad, C. Wilhelm, and M. Breckwoldt, "Seminal tract infections: impact on male fertility and treatment options," Human Reproduction Update, vol. 4, no. 6, pp. 891-903, 1998.

[6] F.-M. Kohn, I. Erdmann, T. Oeda, K. F. El Mulla, H. G. Schiefer, and W.-B. Schill, "Influence of urogenital infections on sperm functions," Andrologia, vol. 30, supplement 1, pp. 73-80, 1998.

[7] M. H. Moustafa, R. K. Sharma, J. Thornton et al., "Relationship between ROS production, apoptosis and DNA denaturation in spermatozoa from patients examined for infertility," Human Reproduction, vol. 19, no. 1, pp. 129-138, 2004.

[8] J. P. Jarow, J. A. Kirkland Jr., and D. G. Assimos, "Association of antisper antibodies with chronic nonbacterial priostatitis," Urology, vol. 36, no. 2, pp. 154-156, 1990.

[9] World Health Organization (WHO), WHO Laboratory Manual for the Examination and Processing of Human Semen, World Health Organization, Geneva, Switzerland, 5th edition, 2010.

[10] World Health Organization, WHO Laboratory Manual for the Examination of Human Semen and Sperm-Cervical Mucus Interaction, Cambridge University Press, Cambridge, UK, 4th edition, 1999.

[11] T. Domes, K. C. Lo, E. D. Grober, J. B. M. Mullen, T. Mazzulli, and K. Jarvi, "The incidence and effect of bacteriospermia and elevated seminal leukocytes on semen parameters," Fertility and Sterility, vol. 97, no. 5, pp. 1050-1055, 2012.

[12] Clinical Laboratory Standards Institute, M100-s24: Performance Standards for Antimicrobial Susceptibility testing: Twenty-First Informational Supplement, Clinical Laboratory Standards Institute, Wayne, Pa, USA, 2014.

[13] I. D. Harris, C. Fronczak, L. Roth, and R. B. Meacham, "Fertility and the aging male," Reviews in Urology, vol. 13, no. 4, pp. e184e190, 2011.

[14] S. Jajoo and K. Kalyani, "Prevalence of abnormal semen analysis in patients of infertility at a rural setup in Central India," International Journal of Reproduction, Contraception, Obstetrics and Gynecology, vol. 2, pp. 161-164, 2013.

[15] A. T. Owolabi, O. B. Fasubaa, and S. O. Ogunniyi, "Semen quality of male partners of infertile couples in Ile-Ife, Nigeria," Nigerian Journal of Clinical Practice, vol. 16, no. 1, pp. 37-40, 2013.

[16] L. Alekwe, A. I. Osamudiamen, and L. O. Aberare, "Association between bacteriospermia and abnormal semen characteristics," Pakistan Journal of Medical and Health Sciences, vol. 7, no. 1, pp. 3-6, 2013.

[17] M. Golshani, S. Taheri, G. Eslami, A. A. Suleimani Rahbar, F. Fallah, and H. Goudarzi, "Genital tract infection in asymptomatic infertile men and its effect on semen quality," Iranian Journal of Public Health, vol. 35, no. 3, pp. 81-84, 2006.
[18] N. Mogra, A. Dhruva, and L. K. Kothari, "Non-specific seminal tract infection and male infertility: a bacteriological study," Journal of Postgraduate Medicine, vol. 27, no. 2, pp. 99-104, 1981.

[19] E. Cottell, R. F. Harrison, M. McCaffrey, T. Walsh, E. Mallon, and C. Barry-Kinsella, "Are seminal fluid microorganisms of significance or merely contaminants?" Fertility and Sterility, vol. 74, no. 3, pp. 465-470, 2000.

[20] I. N. Isaiah, B. T. Nche, I. G. Nwagu, and I. I. Nnanna, "Current studies on bacterospermia the leading cause of male infertility: a protégé and potential threat towards mans extinction," North American Journal of Medical Sciences, vol. 3, no. 12, pp. 562-564, 2011.

[21] G. Merino, S. Carranza-Lira, S. Murrieta, L. Rodriguez, E. Cuevas, and C. Moran, "Bacterial infection and semen characteristics in infertile men," Archives of Andrology, vol. 35, no. 1, pp. 43-47, 1995.

[22] M. Damirayakhian, R. S. Jeyendran, and S. A. Land, "Significance of semen cultures for men with questionable semen quality," Archives of Andrology, vol. 52, no. 4, pp. 239-242, 2006.

[23] T. Balmelli, J. Stamm, M. Dolina-Giudici, R. Peduzzi, A. Piffaretti-Yanez, and M. Balerna, "Bacteroides ureolyticus in men consulting for infertility," Andrologia, vol. 26, no. 1, pp. 35-38, 1994.

[24] K. Ostwal, "Correlation of bacterospermia with primary infertility in males," Indian Research Journal, vol. 1, no. 2, pp. 1-9, 2014.

[25] E. Moretti, S. Capitani, N. Figura et al., "The presence of bacteria species in semen and sperm quality," Journal of Assisted Reproduction and Genetics, vol. 26, no. 1, pp. 47-56, 2009.

[26] D. M. Rodin, D. Larone, and M. Goldstein, "Relationship between semen cultures, leukospermia, and semen analysis in men undergoing fertility evaluation," Fertility and Sterility, vol. 79, supplement 3, pp. 1555-1558, 2003.

[27] F. O. Ekhaise and F. R. Richard, "Common bacterial isolates associated with semen of men complaining of infertility in University of Benin Teaching Hospital (U.B.T.H), Benin City, Nigseria," World Journal of Medical Sciences, vol. 3, no. 1, pp. 2833, 2008.

[28] G. Merino, S. Carranza-Lira, S. Murrieta, L. Rodriguez, E. Cuevas, and C. Morán, "Bacterial infection and semen characteristics in infertile men," Archives of Andrology, vol. 35, no. 1, pp. 43-47, 1995.

[29] R. E. Berger, L. E. Karp, R. A. Williamson, J. Koehler, D. E. Moore, and K. K. Holmes, "The relationship of pyospermia and seminal fluid bacteriology to sperm function as reflected in the sperm penetration assay," Fertility and Sterility, vol. 37, no. 4, pp. 557-564, 1982.

[30] M. P. McGowan, H. G. Burger, H. W. G. Baker, D. M. de Kretser, and G. Kovacs, "The incidence of non-specific infection in the semen in fertile and sub-fertile males," International Journal of Andrology, vol. 4, no. 6, pp. 657-662, 1981.

[31] W. Ombelet, E. Bosnians, M. Janssen et al., "Semen parameters in a fertile versus subfertile population: a need for change in the interpretation of semen testing," Human Reproduction, vol. 12, no. 5, pp. 987-993, 1997.

[32] D. Sanocka-Maciejewska, M. Ciupińska, and M. Kurpisz, "Bacterial infection and semen quality," Journal of Reproductive Immunology, vol. 67, no. 1-2, pp. 51-56, 2005.

[33] T. Diemer, P. Huwe, H. W. Michelmann, F. Mayer, H. G. Schiefer, and W. Weidner, "Escherichia coli-induced alterations of human spermatozoa. An electron microscopy analysis," 
International Journal of Andrology, vol. 23, no. 3, pp. 178-186, 2000.

[34] V. Prabha, R. Sandhu, S. Kaur et al., "Mechanism of sperm immobilization by Escherichia coli," Advances in Urology, vol. 2010, Article ID 240268, 6 pages, 2010.

[35] A. Nabi, M. A. Khalili, I. Halvaei, J. Ghasemzadeh, and E. Zare, "Seminal bacterial contaminations: probable factor in unexplained recurrent pregnancy loss," Iranian Journal of Reproductive Medicine, vol. 11, no. 11, pp. 925-932, 2013.

[36] O. O. Oyeyipo, O. Owhoeli, and C. A. Iwuji, "The prevalence of bacteriospermia in patients with clinically diagnosed HIV/AIDS in Port Harcourt," International Journal of Health Research, vol. 5, no. 1, pp. 29-33, 2013.

[37] P. Huwe, T. Diemer, M. Ludwig, J. Liu, H. G. Schiefer, and W. Weidner, "Influence of different uropathogenic microorganisms on human sperm motility parameters in an in vitro experiment," Andrologia, vol. 30, supplement 1, pp. 55-59, 1998.

[38] M. S. Bornman, "Microbial flora in semen of infertile African men at Gasrankuwa hospital," Journal of Andrology, vol. 22, no. 2, pp. 118-121, 1990.

[39] W. Eggert-Kruse, G. Rohr, W. Ströck, S. Pohl, B. Schwalbach, and B. Runnebaum, "Anaerobes in ejaculates of subfertile men," Human reproduction update, vol. 1, no. 5, pp. 462-478, 1995.

[40] A. A. Kiessling, B. M. Desmarais, H.-Z. Yin, J. Loverde, and R. C. Eyre, "Detection and identification of bacterial DNA in semen," Fertility and Sterility, vol. 90, no. 5, pp. 1744-1756, 2008. 


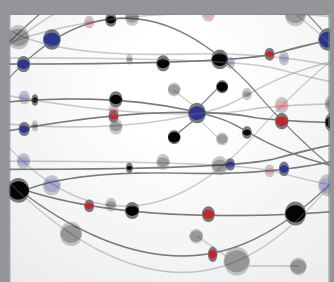

The Scientific World Journal
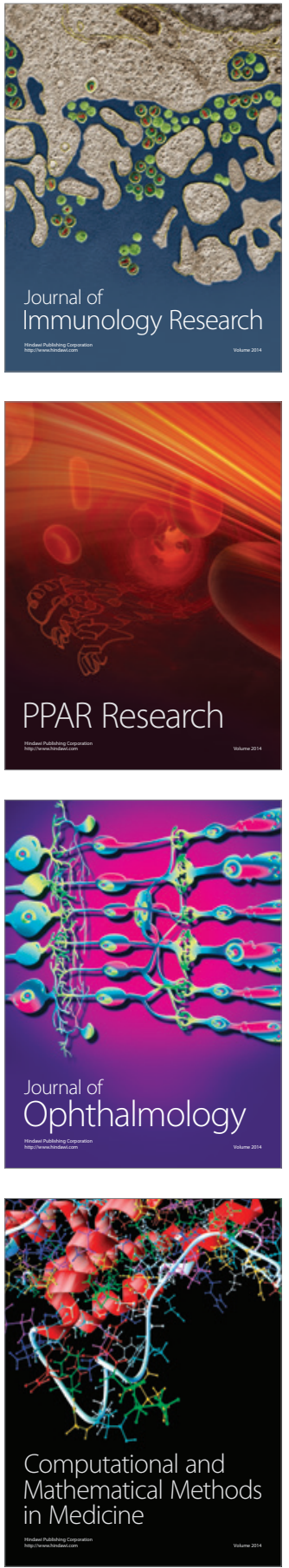

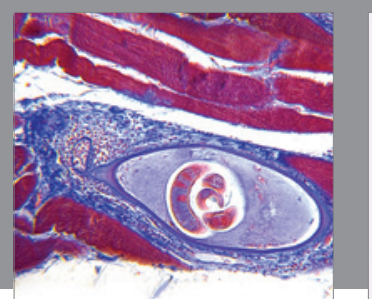

Gastroenterology Research and Practice

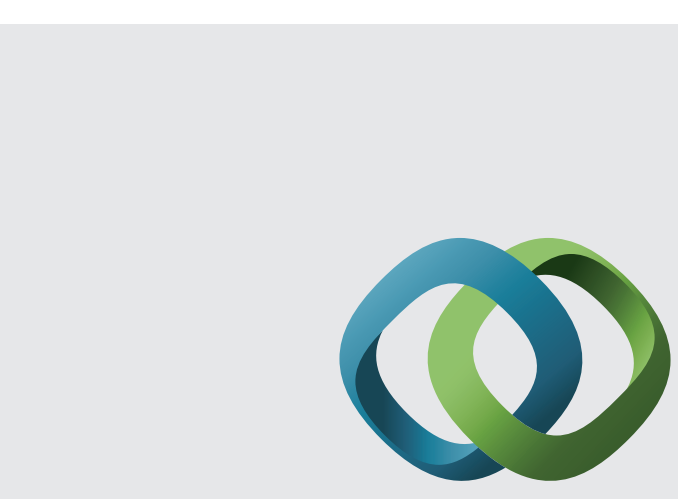

\section{Hindawi}

Submit your manuscripts at

http://www.hindawi.com
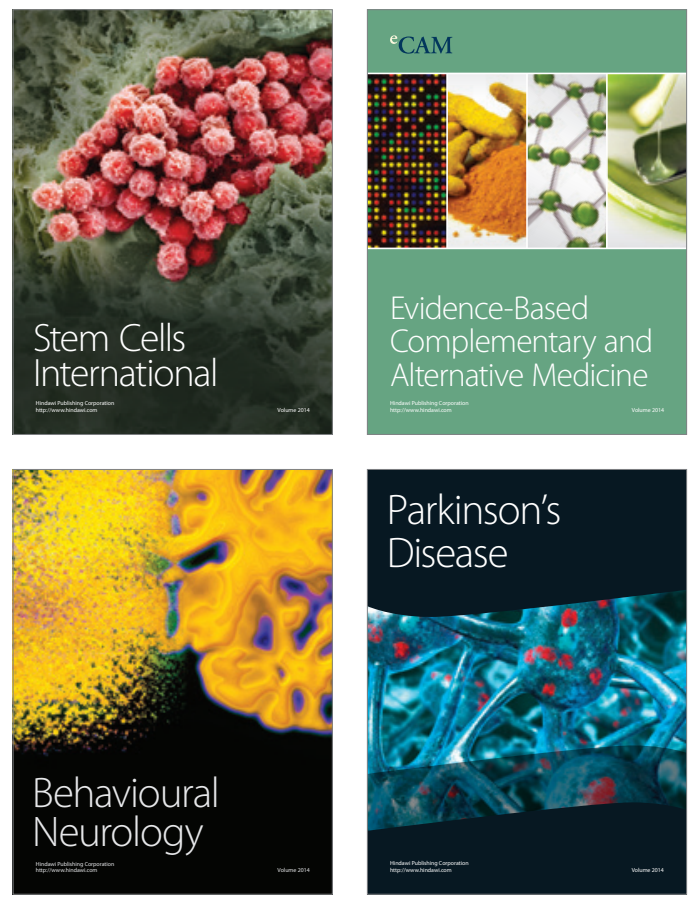
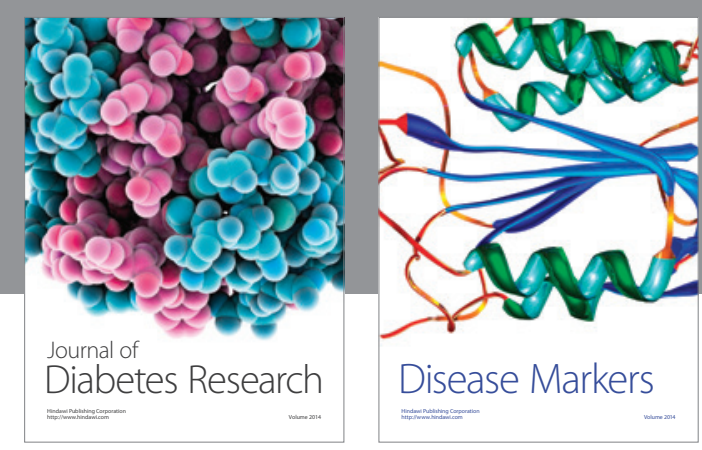

Disease Markers
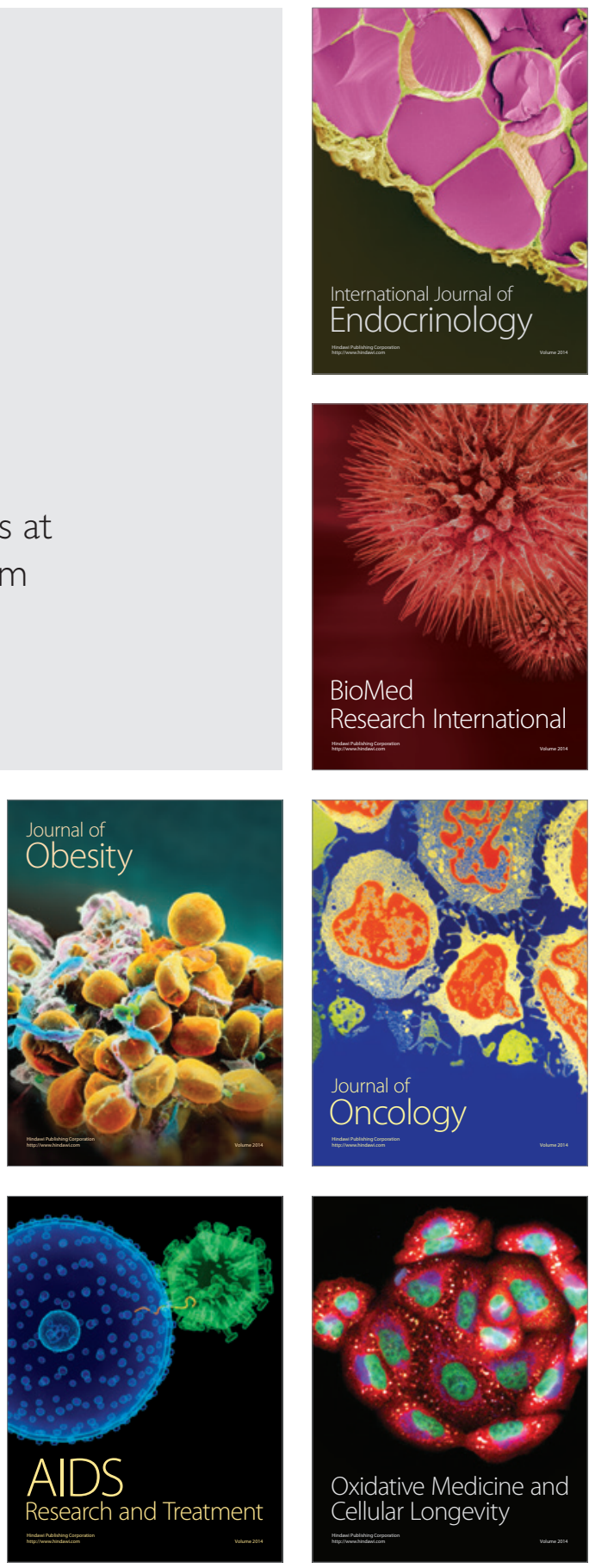